DOI https://doi.org/10.36059/978-966-397-117-9/247-266

\title{
RESPONSIBILITY FOR ADMINISTRATIVE MISCONDUCT
}

\section{Petkov S. V.}

\section{INTRODUCTION}

The urgent issue of Ukrainian administrative law reformation should be the task connected with the creation of national scientific model of administrative delictology, reflecting adequately the essential novelty in social role definition as well as the purpose of the branch of law mentioned. In administrative delictology the guarantee of supremacy of law principle is of great significance, according to which the main characteristics in determining the administrative law should perform not "administrative", and even more, not its "punitive" functions, but other two functions such as "law-providing", associated with the provision of exercise of human rights and freedoms; "human rights protecting", associated with the protection of violated rights by public authorities.

Public legal relations in the state are decisive for its very existence. Of course, sometimes there are cases of violation of the established mechanism of interaction of different subjects, so administrative misconduct is committed. And then the necessity of mandatory return of relations in the legal direction and punishment of a guilty person in the occurred incidents has arisen. The theory of administrative law sets its task as determination of the legal nature of such misconduct administrative torts - the subject structure and their relation with other types of misconduct.

\section{Administrative Delictology as a Specific Part of Administrative Law}

Administrative delictology is a specific part of administrative law along with a general (administrative law theory) and special (administrative activity) part. In order to outline a socio-legal model of implementation of legislation on torts it is necessary to present a range of legal axioms, namely:

- Administrative delinquency - a special type of torts (legal offences); 
- On the level of public danger, administrative torts are divided into administrative crimes and administrative misconduct;

- The subject of an administrative tort can only be a person (a public one, civil servant, etc.) vested with powers;

- Administrative offence is a social phenomenon and, thus, a special kind of public offence.

The list of axioms given above is not exhaustive, but it gives the opportunity to derive the main formula for the place of an administrative tort as well as administrative delictology in the system of law in general and in the legislation of Ukraine in particular during its reformation and bringing it into line with global requirements. Thus, the administrative tort should be considered an unlawful, guilty (intentional or negligent) action or inaction committed by a person vested with powers (by an official of public authorities), resulted in material or moral damage to a person (physical, legal) or society.

When it comes to administrative offences, it should be understood that this is a complex social phenomenon, associated with different legal institutions, state mechanisms, etc. Administrative offences are unlawful actions (acts) of officials carrying out public administration. Quite often, public administration is confused with economic activity, officials of public authorities with company administrators, therefore, in legal acts, for example, in the Code on Administrative Offences of Ukraine, there are articles on the responsibility of heads of private law legal entities for certain wrongful acts. In the same way, misunderstanding of the basic nature of administrative phenomena leads to the fact that state administration is perceived as an activity of a district police inspector for the identification of persons who manufacture home-made alcohol or spread sexually transmitted diseases.

All violations of law can be divided into types in accordance with such a criterion as the field in which they are committed: medical, road transport, state administration, etc.

The violation of law can be divided into types according to the subjects that commit them: citizens, stateless persons or foreigners, civil servants, military servicemen. Some kind of distinction is also made between administrative offences depending on the position of the offender: whether it is an official of state authorities or local selfgovernment, or an employee of law enforcement or judicial bodies. The 
following question is of great significance: whether they were elected or appointed; if it was a position of a public political figure or state official. That is, for generic gradation, we can use a huge number of criteria and approaches; the only fact remains that the person, who can commit an administrative offence and, accordingly, be brought to administrative liability, must be in the public service.

The issues of administrative responsibility of officials of public authorities were considered in the national legal science even in the Soviet times. However, at that time, responsibility for administrative offences was perceived as a responsibility in general for any misconduct and executed under the non-judicial (administrative) procedure. Therefore, there was a confusion of concepts. In addition, together with administrative legal relations, economic relations were mixed too. Economic activity was carried out only by the state. The directors of enterprises and the whole apparatus were state officials or representatives of the government, namely, government administrators.

As a result, in the Soviet Union, the responsibility for economic misconduct was considered as administrative. This was clear, since only the state could conduct economic activity in the interests of the state. In addition, all actions that violated any rule or norm of conduct were perceived as actions against the state. At present, legislation created in the middle of the last century is in force; most scholars were educated in this period. It was a different system, and, consequently, another model of the state and a model of legal relations. Today, post-Soviet countries are experiencing a reception of Soviet law, instead of developing civilized law. This circumstance led to maintenance of the provisions of Part 1 of Art. 9 of the Code on Administrative Offences of Ukraine, defining the term "administrative offence (misconduct)" as an unlawful, guilty (intentional or negligent) action or inaction that infringes on public order, property, rights and freedoms of citizens, on the established procedure of administration and for which the law stipulates administrative responsibility"1. It is obvious that the use of the terms "misconduct" and "administrative offence" as equivalent is inappropriate for at least three reasons, namely: firstly, misconduct can not be identical to offence (tort), which does not have a significant public danger, and therefore the offence

\footnotetext{
${ }^{1}$ Кодекс України про адміністративні правопорушення. - К. : Національний Книжковий Проект, 2011. -224 c.
} 
is wider phenomenon and includes both crime and misconduct; secondly, an administrative offence can not be committed by a citizen who does not hold a public position, and again, if we are talking about an administrative offence, then according to the degree of public danger it should be divided into an administrative crime and administrative misconduct; thirdly, misconduct is committed not only in the administrative area, but also there are disciplinary misconduct, customs, tax, medical, road transport misconduct, etc. So, incorrectness and confusion of concepts are laid down even in the division of offences itself, and it does not correspond to the law theory and the methodology of scientific cognition.

At present, the state actually provides immunity to public servants against legitimate demands of citizens to whom they have committed unlawful acts. The only thing that can be done by the victim is to cancel an unlawful act. Citizens not only do not have the right to make responsible, but in fact they do not know how to raise the issue of bringing the civil servant to legal responsibility. Only civil servant can make responsible another civil servant for any type of responsibility. Citizens have the only right to file complaints about the impunity of those who violated their rights ${ }^{2}$.

Officials of public authorities and local self-government perform certain functions of economic nature while carrying out administrative activities. Accordingly, during their economic activity, they may commit certain misconduct. This may be untimely payment of utility bills, and violation of certain sanitary-epidemiological or fire regulations.

Also, officials of public authorities commit other misconduct or crimes and bear responsibility for their commission in accordance with the current legislation. In the case of committing such non-administrative, but economic or other misconduct, there should be an examination on the fact of the misconduct. This proceeding must be carried out by a competent authority or official, and the guilty persons must be held liable for their actions or inactions. We should emphasize that responsibility should be borne by both direct executors and heads of those units where, due to their negligence, the conditions were created led to the commission of an unlawful act.

\footnotetext{
2 Бахрах Д.Н. Как защитить себя от произвола / Д.Н. Бахрах // Российская юстиция. - 2003. № $9 .-$ С. 5 .
} 
The grounds for administrative responsibility for offences encroaching upon exercise of the people's will and the established procedure for its provision are an administrative misconduct violating the established procedure for exercise of the people's will. The object of these administrative offences is public relations in the field of exercise of the people's will and the established procedure of its provision ${ }^{3}$.

Under modern conditions of the state-creating, the subject of administration is responsible for all the adverse effects caused by unlawful or inefficient use of powers. It is this approach that is one of the conditions for the effective functioning of state administration, and, consequently, political stability in the state. As practice shows, the main emphasis is placed on the rights of public authorities, officials, and the responsibility is not always sufficiently distinguished, in particular for false decisions and actions, and inaction ${ }^{4}$.

\section{Administrative Torts as Unlawful Actions of Officials of Public Authorities}

An administrative tort should be considered as an unlawful, guilty (intentional or negligent) action or inaction committed by a person vested with powers (an official of public authorities), resulted in the material or moral damage to the person (physical, legal) or society.

The issue of administrative torts is governed by a wide range of normative-legal acts. However, basic provisions of law, providing for the responsibility for administrative torts committed by officials, laid down in Article 14 of the Code on Administrative Offences of Ukraine, namely, "Responsibility of Officials": "Officials are subject to administrative responsibility for administrative offences related to non-observance of established rules in the field of protection of the administration order, state and public order, nature, public health and other rules ensuring execution of which is included to their official duties" 5 .

\footnotetext{
3 Циверенко Г.П. Адміністративні правопорушення, що посягають на здійснення народного волевиявлення та встановлений порядок його забезпечення в аспекті проекту Виборчого кодексу України [Електронний ресурс] / Г.П. Циверенко // Форум права. - 2010. - № 4. - С. 905-909. - Режим доступу: http://www.nbuv.gov.ua/ejournals/FP/2010-4/10cgpvku.pdf.

${ }^{4}$ Малиновський В.Я. Державне управління : навч. посіб. / В.Я. Малиновський. - Луцьк : Вежа : Вол. держ. ун-ту ім. Лесі Українки, 2000. - 558 с.

${ }^{5}$ Кодекс України про адміністративні правопорушення від 7 грудня 1984 р. // Відомості Верховної Ради Української РСР. - 1984. - Додаток до № 51. - Ст. 1122 (із змінами та доповненнями).
} 
In this norm, the main list of functions of officials has been stipulated. The analysis of this article gives grounds for the conclusion that the concept of an official in the Code on Administrative Offences of Ukraine is directly related to the performance of such a person's official duties, regardless of where they hold a position: in the structure of a state body, institution or other organization.

Administrative responsibility is a legal responsibility of officials of public authorities. It is even more appropriate to say the bodies of public authorities, because officials of local self-government also perform public functions. It is they who provide the great share of administrative services to citizens.

Thus, administrative responsibility is a form of legal responsibility. As legal responsibility is divided into responsibility for misconduct and responsibility for crimes, in the same way administrative responsibility can be applied for administrative misconduct and administrative crimes. It should be noted that the peculiarity of responsibility of officials of public authorities is that they bear, in addition to administrative ones, also labor responsibility (labor misconduct is described in the Labor Code), as well as all other types of responsibility for violation of the norms of confidentiality regimes, permissive requirements.

The crimes in the field of administrative activity, in particular, involve: Art. 364 "Abuse of power or official position"; Art. 365 "Excess of power or official powers"; Art. 3652 "Abuse of powers by persons providing public services"; Art. 366 "Service falsification"; Art. 367 "Service negligence"; Art. 368 "Bribery"; Art. 368. "Illegal Enrichment"; Art. 3684 "Bribing a person who provides public services"; Art. 369 "Offering or giving a bribe"; Art. 3692 "Improper influence"; Art. 370 "Provocation of bribes or commercial bribery".

A state official bears disciplinary responsibility for an official misconduct (and in some cases, administrative one), for an official crime - criminal responsibility. It is correct to distinguish the official misconduct from the official crime correctly in each individual case only by carefully examining the circumstances that accompany these actions (or inaction), and taking into account the specified criterion ${ }^{6}$.

\footnotetext{
${ }^{6}$ Якуба О.М. Советское административное право (Общая часть) / О.М. Якуба. - К. : Вища школа, 1975. - C. 41 .
} 
The term "public service" is relatively new for our country. For the first time, the concept of "public service" has been used in the Code of Administrative Judicial Procedure to outline the substantive jurisdiction of administrative cases. Therefore, according to the Code of Administrative Judicial Procedure of Ukraine, the public service is the activity on state political positions, professional activity of judges, prosecutors, military service, alternative (non-military) service, diplomatic service, other state service, service in the authorities of the Autonomous Republic of Crimea, and local self-government bodies.

The Supreme Administrative Court of Ukraine in the Statement on the study and generalization of the procedure for consideration by administrative courts of disputes concerning acceptance of citizens to the public service, record of service, dismissal from the public service, concludes that the specified norm of the public service stipulates the types of service by the list which is not exhaustive. The Supreme Administrative Court, when distinguishing the types of public service for law enforcement, believes that a legal regulation of their activities, according to which one can determine the types of public activities that deserve attention during the study of judicial practice is significant. It is as follows:

- Activity on state political positions;

- Professional activity of judges;

- State service;

- Service in self-government bodies ${ }^{7}$.

\section{Legislation Governing the Issues of Responsibility in the Field of State Service}

The law, governing the issue of civil service responsibility involves, first of all, the Constitution of Ukraine, in which, although there are no provisions that would determine the model of civil service development, the ideology of the current Constitution speaks about the functioning of the civil service as a democratic institution and reveals its socially oriented nature ${ }^{8}$.

\footnotetext{
7 Довідка про вивчення та узагальнення практики розгляду адміністративними судами спорів 3 приводу прийняття громадян на публічну службу, іiі проходження, звільнення з публічної служби (частина I) [Електронний ресурс]. - Режим доступу: http://www.vasu.gov.ua/. C. 36 .

8 Желюк Т.Л. Державна служба : навч. посіб. / Т.Л. Желюк. - К. : Професіонал, 2005. - 576 с. -
} 
It should be noted that the Code on Administrative Offences of Ukraine, as well as the Laws of Ukraine "On Ratification of the United Nations Convention against Corruption"; "On ratification of the Criminal Law Convention on the fight against corruption" ${ }^{10}$; "On ratification of the Additional Protocol to the Criminal Law Convention on the fight against corruption" "11 "On ratification of the Civil Convention on the fight against corruption" 12 remains the basic legal acts that establishes the responsibility of officials for administrative torts.

Legal acts which are the basis of anticorruption legislation include such Laws of Ukraine: "On Corruption Prevention"13; "On State Service"" ; "On Fundamentals of National Security of Ukraine" 15 and so on.

Among the laws mentioned above, some issues of certain types of the state service are governed by other laws such as: customs service - the Customs Code of Ukraine ${ }^{16}$; diplomatic service - by the Law of Ukraine "On Diplomatic Service"" ; police service - by the Law of Ukraine "On National Police" "18; the service in the security service - by the Law of Ukraine "On the Security Service of Ukraine" 19 ; military service - by the Law of Ukraine "On Military Duty and Military Service"20; state executive service - by the Law of Ukraine "On State Executive Service" ${ }^{21}$. The interrelated laws and normative-legal acts form the

\footnotetext{
${ }^{9}$ Про ратифікацію Конвенції Організації Об'єднаних Націй проти корупції: Закон України 18 жовтня 2006 р. // Відомості Верховної Ради України. - 2006. - № 50. - Ст. 496.

${ }^{10}$ Про ратифікацію Кримінальної конвенції про боротьбу 3 корупцією : Закон України від 18 жовтня 2006 р. // Відомості Верховної Ради України. - 2006. - № 50. - Ст. 497.

${ }^{11}$ Про ратифікацію Додаткового протоколу до Кримінальної конвенції про боротьбу з корупцією : Закон України від 18 жовтня 2006 р. // Відомості Верховної Ради України. - 2006. - № 50. - Ст. 498.

${ }^{12}$ Про ратифікацію Цивільної конвенції про боротьбу з корупцією : Закон України від 16 березня 2005 р. // Відомості Верховної Ради України. - 2005. - № 16. - Ст. 266.

${ }^{13}$ Про запобігання корупції: Закон України від 7 квітня 2014 р. № 3206-VI [Електронний ресурс]. Режим доступу: http://zakon.rada.gov.ua/.

${ }^{14}$ Про державну службу в Україні: Закон України від 17 листопада 2011 р. № 4050-VI // Відомості Верховної Ради України. - 2012. - № 26. - Ст. 273.

${ }^{15}$ Про основи національної безпеки України : Закон України від 19 червня 2003 р. // Відомості Верховної Ради України. - 2003. - № 39. - Ст. 351.

${ }_{17}^{16}$ Митний кодекс України // Відомості Верховної Ради України. - 2012. - № 44-45. - Ст. 552.

${ }^{17}$ Про дипломатичну службу: Закон України від 20 вересня 2001 р. [Електронний ресурс]. Режим доступу: http://zakon.rada.gov.ua/.

${ }^{18}$ Про Національну поліцію : Закон України від 02.07.2015 № 580-VIII [Електронний ресурс]. Режим доступу: http://zakon.rada.gov.ua/.

${ }^{19}$ Про Службу безпеки України : Закон України від 25 березня 1992 р. [Електронний ресурс]. Режим доступу: http://zakon.rada.gov.ua/.

${ }^{20}$ Про військовий обов'язок і військову службу: Закон України від 25.03.1992 № 2232-XII [Електронний ресурс]. - Режим доступу: http://zakon.rada.gov.ua/.

${ }^{21}$ Про державну виконавчу службу : Закон України від 24 березня 1998 р. [Електронний ресурс]. Режим доступу: http://zkdvs.uzh.ukrtel.net/.
} 
anticorruption legislation of Ukraine, which is currently repeatedly systematized in scientific and practical collections of Anticorruption Laws, anticorruption legislation, etc. ${ }^{22}$.

The Code on Administrative Offences of Ukraine has traditionally been considered as a system-forming normative document in the field of administrative responsibility. However, it has been already noted, that the provision of Art. 14 of the Code on Administrative Offences of Ukraine does not meet the requirements of the present because it can not satisfy modern legal practice on the following essential positions: the necessity of introducing into the CAOU an article that, without specifying the direct concept of an official, their types and features, boundaries and peculiarities of bringing to administrative responsibility of officials, actually lists the sections of the code containing articles that provide for the responsibility of this category of citizens of Ukraine, is considered as the minimum necessity. Taking into account the obvious connection between the Criminal Code of Ukraine and the Code on Administrative Offences of Ukraine, some administrative offences differ from crimes only because of their public danger. O. M. Kruglov suggests enshrining in the Code on Administrative Offences of Ukraine not only the range of common objects on which officials infringe, but also the very definition of the term "official", similar to the definition contained in the Criminal Code of Ukraine, only with the amendment to that part of public relations regulated by norms of administrative law ${ }^{23 ; 24}$.

Today, based on the human-centered approach (V. B. Averianov), we are talking about the fact that the authorities provide the citizen with services in the field of state administration (administrative services) and carry out activities to protect their rights and legitimate interests. The implementation of legal responsibility by public authorities with such a purpose is a manifestation of the protection of public (common) interest of society. Accordingly, any violation of public interest should have a negative effect on the offender based on a single algorithm according to

\footnotetext{
${ }^{22}$ Антикорупційні закони України : укл. М.І. Хавронюк. - К. : Атіка, 2009. - 112 с.

${ }^{23}$ Круглов О.М. Доказування і докази у справах про адміністративні правопорушення посадових осіб : дис. ... канд. юрид. наук : 12.00.07 / О.М. Круглов. - Х., 2003. - 223 с.

${ }^{24}$ Пєтков С.В. Побудова сучасної ефективної публічно-правової моделі відносин між владою та громадянином на основі римського права / С.В. Пєтков // Піднесення до права : збірник наукових праць до 60-річчя $з$ дня народження д-ра юрид. наук, професора, заслуженого юриста України Валерія Петровича Пєткова / упоряд.: О.Д. Коломоєць, Н.В. Максименко, А.А. Манжула, Є.Ю. Соболь, P.І. Стецюк, О.А. Троянський, О.С. Юнін ; за заг. ред. С.В. Пєткова. - Кіровоград : ФОП Зєнова Т.М., 2011. - C. 24-34.
} 
the field or branch of the act committed. Thus, based on the development of a fractal model of tort law relations, we consider that responsibility for misconduct committed in any field is public responsibility and can be divided according to the field (branch) into customs, tax, medical, land responsibility, etc. In any case, such gradation does not contradict the fundamentals of the law theory (O. F. Skakun), and moreover, it enables their use as axioms for norm-making (N.O. Armash) under the conditions of reforming the legal system of Ukraine.

The feature of administrative misconduct is illegality (means that action or inaction is expressly prohibited by administrative-legal norms). The feature of illegality also points to impermissibility of the law analogy, which contributes to the strengthening of the rule of law, includes the possibility of bringing to administrative responsibility for acts not provided for by legislation on administrative misconduct; guilty (it foresees the presence of person's attitude to wrongful act and its consequences); punishment (it means that an administrative misconduct is only recognized the unlawful, guilty action for which the law provides for the use of administrative penalties); public danger or social harm.

The legal literature identifies the features characterizing the official as a special subject of legal responsibility: the legal norms on the responsibility of officials for violations in service take into account the features of the service as a type of labor activity; they are subject to increased responsibility, since the consequences of official offences are negatively detected outside the position; establish special measures of responsibility for official offences (reduction in the position, lowering in a special title, deprivation of title of a state official); bringing an employee to one type of responsibility does not mean that the same act qualifies as another type of offences, which results in a certain type of legal responsibility ${ }^{25}$.

In the context of the study conducted, it is worth noting that the concept of a "specific subject" in the meaning of general characteristics of administrative misconduct violates the system of scientific and theoretical coordinates of administrative law. Administrative offence (tort), misconduct or crime, can only be committed by an official of public authority.

\footnotetext{
25 Лазарев Б.М. Специфика ответственности должностных лиц / Б.М. Лазарев // СССР - ГДР: Государственная служба : сб. науч. трудов. - М., 1986.
} 
Such field of state administration as electoral relations requires a special approach in issue of officials' responsibility. According to I. O. Lugovoi, under the conditions where the mass media are full of reports of numerous gross violations of election law, and violations in electoral technologies are acquiring increasingly new forms of mass character, low indexes of administrative responsibility make it possible to conclude that there are serious drawbacks both in the current legislation, and in the activities of state authorities, which, in their functional responsibilities, ensure the rule of law in this area ${ }^{26}$.

We refer again to Art. 14 "Responsibility of Officials". Any action or inaction of officials of public authorities, if at the territory or in the area for which they are responsible, an offence is committed, may be determined as unlawful. In this case, there is a presumption of guilt. If in case of bringing a citizen to responsibility it is necessary to prove his guilt, then, on the contrary, an official must prove his innocence.

If at the territory or in the area for which an official of state authority a citizen, a public organization or other official sees the presence of the offence, in that event, an administrative case must be commenced on the application of the persons concerned. For example, Art. 166-5 on the discrimination of entrepreneurs by the power bodies and management, in case if other official's unlawful actions are detected during consideration, may become the basis for a criminal case against them.

The Law of Ukraine "On Prevention of Corruption" defines a corruptive offence of law as "an act that contains features of corruption committed by a person specified in part one of Article 3 of this Law, for which the law establishes criminal, disciplinary and/or civil-legal responsibility". The revision of the current law does not connect the concept of corruptive offence with administrative misconduct and administrative responsibility. The administrative responsibility begins for so-called "administrative offences related to corruption". The generic object of such offences, stipulated by the Code on Administrative Offences of Ukraine, is public relations that determine the content and procedure for the legal activity of the subjects of power authorities, which is established by the lawmaker. In turn, public relations in the field of

\footnotetext{
26 Луговий І.О. Адміністративна відповідальність за правопорушення, що посягають на здійснення народного волевиявлення та встановлений порядок його забезпечення : дис. ... канд. юрид. наук : 12.00.07 / І.О. Луговий. - Х., 2002. - С. 4.
} 
normal functioning of state administration, public (state) service and related financial, property and other relations may be the direct object ${ }^{27}$.

In accordance with the Code on Administrative Offences of Ukraine $^{28}$, administrative offences associated with corruption are violation of restrictions on the plurality and combination with other types of activity (Article 172-4 of the CAOU); violation of legal restrictions on the receipt of gifts (Article 172-5 of the CAOU); violation of the requirements of financial control (Article 172-6 of the CAOU); violation of the requirements for prevention and settlement of a conflict of interests (Article 172-7 of the CAOU); illegal use of information that has become known to a person in connection with the exercise of official powers (Article 172-8 CAOU); failure to take anti-corruption measures (Article 172-9 of the CAOU); violation of the ban on placement of sports bets related to the manipulation of official sports events (Article 172 9-1 of the CAOU).

Other offences committed by officials can be: violation of the rules of land use (Article 53); distort or conceal the data of the state land cadastre (Articles 53-2); violation of the term for issuance of a state act on the right of ownership of a land plot (Articles 53-5); violation of the legislation on the State Land Cadastre (Articles 53-6); violation of the rules of water resources protection (Article 59); violation of budget legislation (Article 164-12); violation of the legislation on procurement of goods, works and services of state mail (Articles 164-14); unlawful use of state property (Article 184-1 of the CAOU); violation of the procedure or terms for submission of information about orphans and children left without parental care (Article 184-2 CAOU); creation of conditions for organizing and conducting meetings, rallies, street trips or demonstrations in violation of the established procedure (Article 185-2 CAOU); interference with the appearance of a people's assessor in the court (Article 185-5 CAOU); failure to take measures for a separate court order or a separate resolution of a judge or the submission of a prosecutor (Article 185-6 CAOU); evasion from the lawful demands of the prosecutor (Article 185-8 CAOU); disclosure of information about

\footnotetext{
${ }^{27}$ Курс адміністративного права України / за ред. В.В. Коваленко. - К. : Юрінком Інтер, 2012. $808 \mathrm{c}$.

${ }^{28}$ Науково-практичний коментар Кодексу України про адміністративні правопорушення. Станом на 2 квітня 2012 р. / Н.П. Бортник, К.І. Бєляков, С.В. Пєтков, О.І. Остапенко [та ін.] ; за заг. ред. С.В. Пєткова, С.М. Морозова. - К. : Центр учбової літератури, 2012. - 1248 с.
} 
security measures against a person who has been taken into protection (Article 185-11 CAOU); violation of the law on state secrets (Article 2122 CAOU); violation of the right to information (Article 212-3 CAOU); violation of the procedure for the registration, storage and use of documents and other media containing confidential information that is property of the state (Article 212-5 CAOU).

It should be mentioned that all misconduct stipulated in the Code on Administrative Offences of Ukraine, are committed either by citizens or representatives of economic subjects due to negligence, carelessness or neglect by state official, public authorities of their official duties. These actions are made intentionally (Art. 10). For instance, we can give articles connected with violations of the legislation requirements on labor and labor protection (Art. 41), evasion from participation in negotiations concerning conclusion, changes or amendments of collective agreement, deed (Art. 41-1), violation or non-performance of collective agreement, deed (Art. 41-2), failure to present information for collective agreements, deeds conduct (Art. 41-3). In this case officials of public authorities can not know about the fact that violations of these articles of the Code on Administration Offences of Ukraine act at the territory subordinated to them.

An essential factor for the reform of Ukrainian administrative law is that it is based on democratic principles of common European significance from the very beginning. Of course, one must realize that the legal standards existing in the countries around the world, including the administrative-legal standards, are quite diverse, and there is no a "single European" (and even more global) type, so to speak, it does not exist in a pure form. At the same time, there are, of course, some common features of legal institutions already successful in foreign countries, and it is fully justified to be guided by them.

Recently, in a number of countries in Western Europe (Germany, France, Italy, Great Britain, etc.), serious changes have been made in the system of legislation in the field of combating official violations of law. This fact quite clearly proves the need to eliminate such a phenomenon not only abroad, but also in Ukraine. Thus, during the reform of administrative law in relevant legislative drafting works, it would be very useful to take into account and use those principles that have already proven themselves well in the practice of the post-Soviet countries. 


\section{Incompliance of the Code on Administrative Offences of Ukraine of 1984 with the Present-Day Realities}

The Code on Administrative Offences of Ukraine was adopted in 1984. During the same period, similar codes were adopted, based on the Principles of administrative legislation (1980), in all the Union republics, as well as in many countries of the Warsaw Pact and in countries that were in friendly or relations dependent on the USSR. Analyzing the modern Code on Administrative Offences of Ukraine, it should be understood that it has been and remains the Soviet law in its content. That is, a part of legislation, which began to form in the 1920's with the complete rejection of the "bourgeois law", existed in the previous period of history. For more than 70 years of existence, Soviet law was formed as a special legal family, the main feature of which is the priority of public interest over the private. Public law was perceived by Soviet jurisprudence as the state law, and all other legal branches played the role of auxiliary ones.

In understanding of the lawmaker of the Soviet period, all citizens, institutions, departments, ministries, etc. were part of a unified management system whose purpose was to build communism in the whole world. That is why every participant in this development had to comply strictly with the rules of administrative legal relations, and in case of breach of administrative orders, to bear administrative responsibility for this. In accordance with this doctrine, any misconduct of a citizen was considered as offence. Article 176 "Manufacture, storage of home-made alcohol and apparatus for its production" (by the way, without the purpose of marketing) and dozens of others is a vivid reflection of such an approach to administrative law.

However, in the next period of administrative law development in an independent state, the Code on Administrative Offences of Ukraine (as an all-consuming, comprehensive support link of punitive and repressive normative base) was constantly added by the composition of various misconducts, requiring systematization or punitive reaction from officials. "Rules of conduct", "restrictions", "established requirements" and "established procedure" were introduced in law every time. Continuous codification led to nonsense.

All these uncoordinated actions, combined with legal nihilism of the population and legal illiteracy of law enforcement bodies, led to the 
absurdization of procedural part of the Code on Administrative Offences of Ukraine as well when the examination and review turned into raider take-over. The CAOU became a document through which officials frightened entrepreneurs, persons conditionally released from punishment, sexually transmitted diseases distributors, and others. This way, in many articles of the code the "official", "official of authorities" subdivisions, heads, deputy heads, etc. are the subject that imposes penalties, and the subject to which the penalty is imposed.

We are even not surprised by such articles as 164-4 "Untimely delivery of revenues" and others. It is quite clear that Clause 3 of Art. 255 "Persons entitled to draw up protocols on administrative offences", according to which the owner of an enterprise, institution, organization or authorized body has the right to draw up administrative protocols in accordance with Art. 51 "Minor larceny of other's property" and Art. 179 "Brewing of beer, alcoholic, low-alcoholic beverages at production".

Of course, the lawmaker constantly strived to provide the code with administrative content. However, to a greater extent, this led to the emergence of articles such as "Failure to comply with legal requirements of officials of the body ...", to intimidation of entrepreneurs and citizens, while not creating the necessary conditions to meet the basic needs. In addition, due to the disorder in creation of ministries, departments, agencies (in accordance with decrees and orders of the executive branch of power), the need for relevant changes in the codified law no longer corresponds to the very principle of the division of power into legislative, executive and judicial.

Today it is reasonable to carry out step-by-step codification of administrative legislation norms in particular fields and institutions of administrative-legal regulation.

This codification process can be conventionally divided into certain stages. Of course, it is impossible to talk about their exact division, but we emphasize that the relevant processes had started right before the start of the administrative reform in 1998. The legislation requires the transfer of the norms of the Code on Administrative Offences of Ukraine to the basic codes: the Land Code, the Code of the mineral resources, etc., in the same way it was done during the time of Customs legislation creation.

It should be emphasized that structuring the administrative law can be carried out by issuing codified acts on particular fields and institutions 
of administrative-legal regulation ${ }^{29}$. Some parts of the articles and certain articles of the code, together with other laws and by-laws, may become full codes: the Medical Code of Ukraine, Social, Informational, Road Transport Codes, etc. Fourthly, the creation of the Administrative Code of Ukraine directly as a code of substantive law, which will contain rules regulating the activities of state authorities and state authorities for committing official offences.

Previously V. B. Averianov strongly affirmed that "in the system of administrative law there should be regulation of administrative responsibility of all types, which are now regulated by secondary legal branches (financial, economic law, etc) ${ }^{30}$. It is also emphasized that administrative law has polycentric structure of normative set, as opposed to the structurally mono-centric (with one profile code) branches ${ }^{31}$. Therefore, it is logical to propose to adopt, among other codes (financial, law enforcement, medical, etc.) a separate code, which regulates issues of responsibility of officials towards citizens (society) and a person, rules of conduct of officials (state employees). It should also contain rules on administrative responsibility for the commission of unlawful actions by the administration. In the same code, a proceeding in an administrative offence case (administrative procedures, administrative penalties, etc.) should be filed ${ }^{32}$.

The same normative-legal act should define the concept of administrative misconduct as an act that constitutes a violation of administrative legal relations (by the official, the representative of the government) of the provisions of law by the subject as well. The role of such a codified act will be successfully played by the reviewed Code on Administrative Offences of Ukraine.

What should the Code of Ukraine on Administrative Offences contain? First, there must be the rules and norms of behavior of state officials and other state employees who carry out administrative activity.

\footnotetext{
29 Пєтков С.В. Кодифікація законодавства про відповідальність - основа адміністративноправового регулювання діяльності публічної влади в Україні / С.В. Пєтков // Держава та регіони. Серія: Право. - 2009. - № 1. - С. 84-89.

30 Авер'янов В.Б. Реформування українського адміністративного права: необхідність оновлення науково-теоретичних засад / В.Б. Авер'янов // Актуальні проблем и сучасної науки в дослідженнях молодих вчених. - Сімферополь, 2005. - Спеціальний випуск : у 2 ч. - Ч. 1. - С. 24-30.

31 Державне управління: проблеми адміністративно-правової теорії та практики / [В.Б. Авер'янов, О.Ф. Андрійко, Ю.П. Битяк та ін.] ; за заг. ред. В.Б. Авер'янова. - К. : Факт, 2003. - С. $43-47$.

32 Пєтков С.В. Громадський порядок: місце й роль місцевої міліції в протидії проступкам проти громадського порядку / С.В. Пєтков // Право та державне управління. - 2010. - № 1. - С. 44-55.
} 
These norms are specified in the Law of Ukraine "On Citizens' Appeal", in job descriptions that regulate the relations of officials with citizens. Secondly, there must be the norms concerning administrative misconduct. At present, these norms are contained in both anti-corruption legislation and the Code on Administrative Offences of Ukraine. Thirdly, the peculiarities of proceedings in cases of administrative misconduct, among which should be stipulated that the control over the activities of state officials is carried out by the heads of the relevant bodies and services; internal security services, the public prosecutor's office and the public.

Thus, with the introduction of the reviewed Code on Administrative Offences of Ukraine instead of the universal, comprehensive role assigned to administrative law in the Soviet law-making and law enforcement system, where it justified and confirmed the legal administrative party's ambition and communist engagement of state power in all, without exception, public and private relations, administrative law will take a worthy place among other public legal relations, consolidating its leading significance in public law.

Today, administrative law governing administrative activities of bodies, public officials is a chaotic accumulation of norms, rules, requirements and techniques that do not enough correlate with each other. A vivid representation of the Soviet law reception is the Code on Administrative Offences of Ukraine, as well as other codes, laws, instructions, rules, etc. In many cases, the illegal activity of officials of public authorities is a reflection of both the legal system established in the state and the general state of legal relations in which all citizens of the country take part. The saddest thing is that at the moment, creation of the latest European legislation does not mean leaving the legal dead end in which our society got stuck. Under European legislation, the Asian essence of patriarchal relations is hidden. Legislation is used as a "screen" or as a means to hide the self-interested actions of officials and their business partners.

Today, during the time of crisis that, in various manifestations, has begun to put tough conditions for all mankind once again, it is critical to find out what we really mean when we talk about law, legal relations, delictology, responsibility, etc. Political scientists, sociologists, legal scholars state that we must contemplate an interesting socio-political phenomenon of the transition from one system of the state (socialist) to 
another (capitalist), while distorting both the dogmas of the first and the postulates of the second. Therefore, even in the most generalized sense, administrative delictology should be defined not as a "managerial" or "punitive" law, but as "law to ensure and protect human rights". Of course, the main task is not to give a new scientific interpretation of the concept of administrative delictology, but give the interpretation corresponding to the law theory, the essence of phenomenon, and so it can be implemented in new approaches to the analysis and coverage of this institution, and, most significantly - reflected in the administrative legislation adequately.

The state is a manifestation of democracy. Normative acts (laws and by-laws) must be examined carefully for compliance with democratic principles. The actions of each official must be constantly monitored and verified by the public, by any citizen. And in case of detecting any minor violations of law or resolution as well as in actions of the official of public authority, such act should be cancelled, and victims should receive indemnification. Every offence, every attempt to distort the very essence of law, must be stopped, and guilty persons must be punished.

The construction of a democratic legal social state as well as the further development of civil society require the introduction of new conceptual foundations of public authority activities based on international standards. Under the modern economic, political, social conditions, the state faces the primary task - to improve the current legislation in the direction of increasing its efficiency, in order to ensure manageable activity of state authorities, improve the management of all socio-economic fields of life in the country, ensure the fulfillment of assumed obligations by the government and requirements of international organizations.

Steps to bring Ukrainian legislation to the world standards should be taken in a complex and coordinated manner and avoid creating additional conflicts in the country's legal system. The transparency of the process should be ensured by extensive discussions with the public, scientific community and the popularization of legislative acts of the authorities among the people.

The proposed approach should create the theoretical basis for creation of a system of normative and legal acts in the area of responsibility for public misconduct. In accordance with the hierarchy of 
normative legal acts, the construction of this system should start from the Basic law, covering the basic principles, concepts and stages of proceedings in cases of public misconduct. Laws and by-laws adopted in compliance with the provisions of the Basic law will require to be technically reviewed in the future in accordance with the requirements of standard norm-making technology and international standards.

\section{CONCLUSIONS}

Based on the study conducted and designing the fundamental twodimensional scheme of tort division in accordance with type-generic nature, we can state that this is the simplest equation of public relations, where a clear algorithm is used: tort (offence) is divided by the degree of public danger to a crime and misconduct; the object of the offence (by type) is public relations; the range of public relations (rules of conduct), for violation of which comes the responsibility (the person, whose guilt has been proved, is punished), it is determined by law; the object of offence on the basis of generic feature is the field of public relations, in which (against the rules, norms governing these relations) a tort is committed; direct objects of violations can also be grouped, united, separated into different groups, types, subgroups depending on certain features. Moreover, in order to clarify such a scheme in delictological studies, we can introduce other components in this equation as well: institutions, regimes or subjective attributes, etc. With appropriate logical and gradual analysis, as a result of such actions, we will obtain a more comprehensive representation of the phenomenon studied.

In such scheme administrative torts should be placed in a vertical rather than a horizontal plane, i.e. they are also carried out in a certain field, namely, in the field of state administration. They can only be executed by officials with the state powers. Of course, these officials can work in different domains of social and economic life of the country, but they are united by a common feature - the subject of committing offence (tort), either crime or misconduct. This is a fundamental difference of the administrative delictology concept which is proposed. It is in this way that justice and true equality before the law can be achieved, being the integral parts of sovereignty of the people.

Improving the legislation of Ukraine in accordance with the concept of mutual responsibility of citizens and the state will contribute to the 
further development of Ukrainian law and society in the direction of increasing the responsibility of public authorities, reducing corruption and protecting human and citizens' rights and freedoms, and educating citizens in the spirit of respect for the legislation, the law and the state.

\section{SUMMARY}

The article deals with the issue of responsibility for administrative misconduct. Public legal relations in the state are decisive for its very existence. Of course, sometimes there are cases of violation of the established mechanism of interaction of different subjects, so administrative misconduct is committed. And then the necessity of mandatory return of relations in the legal direction and punishment of a guilty person in the occurred incidents has arisen. The theory of administrative law sets its task as determination of the legal nature of such misconduct - administrative torts - the subject structure and their relation with other types of misconduct.

The fundamental two-dimensional scheme of tort division in accordance with type-generic nature is characterized. In such scheme administrative torts should be placed in a vertical rather than a horizontal plane, i.e. they are also carried out in a certain field, namely, in the field of state administration. They can only be executed by officials with the state powers. Of course, these officials can work in different domains of social and economic life of the country, but they are united by a common feature - the subject of committing offence (tort), either crime or misconduct.

\section{Information about the author:}

Petkov S. V.

Doctor of Judicial Sciences, Professor,

Deputy Head of the Department, Head of the Department of National Security of the Department of Anti-Corruption Legislation and Justice and Security of the Ministry of Justice of Ukraine 